\title{
DIAGNOSTIC VALUE OF SERUM N-TERMINAL PRO B-TYPE NATRIURETIC PEPTIDE FOR LEFT VENTRICULAR DYSFUNCTION IN HYPERTENSIVE CASES
}

\author{
RAJU DSSK*, ANIL KUMAR MUNTA, BASHA SJ \\ Department of Biochemistry, Maharajah's Institute of Medical Sciences, Nellimarla, Vizianagaram - 535 217, Andhra Pradesh, India. \\ Email: dsskraju@gmail.com
}

Received: 03 January 2017, Revised and Accepted: 12 January 2017

\begin{abstract}
Objective: Left ventricular hypertrophy ( $\mathrm{LVH})$ is an independent risk factor for all cardiovascular complication of hypertension (HTN), in this group, early detection is very important for better management. Therefore, the aim of our study is to evaluate cardiac markers in HTN with LVH.

Methods: The study comprised 95 patients with the evidence of HTN. These cases were further divided into two groups, i.e., HTN without LVH and HTN with LVH groups. We assessed blood pressure, electrocardiography, and echocardiography. All the cardiac markers were assessed.

Results: In the cases of LVH with HTN group, the serum cardiac parameter such as N-terminal pro-brain natriuretic peptide (NT-proBNP) was significantly raised. However, the serum myoglobin and creatine kinase-MB (CK-MB) did not showed any significant rise when compared with control. In the cases of LVH without HTN, all these three parameters not have shown any significant raise when compared with control.
\end{abstract}

Conclusion: Apart from imaging techniques, the assessment of serum NT-proBNP act as better marker for identifying LVH than the traditional markers such as CK-MB and myoglobin.

Keywords: Hypertension, Left ventricular hypertrophy, N-terminal pro-brain natriuretic peptide, Creatine kinase-MB, Myoglobin.

(C) 2017 The Authors. Published by Innovare Academic Sciences Pvt Ltd. This is an open access article under the CC BY license (http://creativecommons. org/licenses/by/4. 0/) DOI: http://dx.doi.org/10.22159/ajpcr.2017.v10i4.16908

\section{INTRODUCTION}

Hypertension (HTN) with left ventricular hypertrophy (LVH) is an important predictor for cardiovascular events. LVH increases the risk for atrial fibrillation, diastolic heart failure, systolic heart failure, and sudden death in patients with HTN [1]. The mechanisms responsible for progression to hypertrophy include not only a response to the mechanical stress from elevated blood pressure but also the influences of neurohormones, growth factors, and cytokines. Electrocardiography (ECG) is recommended and commonly employed in the diagnosis of LVH. However, the sensitivity and specificity of ECG is poor for the diagnosis. Echocardiography is an imaging technique which is more sensitive and specific for the diagnosis of LVH when compared with ECG. However, it is not possible to perform echocardiography in all the hypertensive patients in all the time [2]. Hence, there is a need of inexpensive and noninvasive method for the early diagnosis of $\mathrm{LVH}$ associated with HTN [3].

Circulating peptides play a major role in the early detection of cardiovascular disease, but still, it is inconclusive in case of LVH. The Brain natriuretic peptides (BNP) have attracted much attention for LVH. BNP belong to a family of vasopeptidase hormone that have main role in regulating blood pressure and volume through direct effect on kidney and systemic vasculature and represent a favorable aspect of neurohumoral activation [4]. The BNP and N-terminal pro-brain natriuretic peptide (NT-proBNP) is released from ventricular myocytes in response to ventricular wall tension and wall stretch, which are released in equimolar amount into circulation $[5,6]$.

In systemic circulation, the BNP interact with natriuretic peptide receptor type $A$ and causes increased cyclic guanosine monophosphate production, which will mediate different biological effects. BNP mostly eliminated by peptide receptor type $\mathrm{C}$ or proteolysis of endopeptidases. These enzymes found in liver, lung, vascular endothelium, and kidney. But NT-proBNP principally cleared by renal excretion $[7,8]$. The circulating BNP half-life is 23 min. The inactive fragment of BNP, NTproBNP has a much longer half-life (60-120 minutes) this difference makes NT-proBNP as a better biomarker for diagnosis LVH, but the glomerular filtration should be within the normal $[9,10]$.

Myoglobin and creatine kinase-MB (CK-MB) are common traditional cardiac biomarkers for myocardial infarction [11] but not raised in LVH. The aim of this study is to determine the role of NT-proBNP in assessing the LVH associated with HTN in compared to traditional serum cardiac biomarkers such as myoglobin and CK-MB.

\section{METHODS}

\section{Selection of control}

The control group comprised healthy individuals $(\mathrm{n}=50)$ with age and sex matched who are free from features of cardiovascular aliments.

\section{Selection of cases}

The study group comprised hypertensive patients $(n=95)$ who were admitted into Medical Unit and attending OPD of MIMS Hospital, Nellimarla. The cases were further divided into two groups, i.e., hypertensive without $\mathrm{LVH}(\mathrm{n}=45)$ patients and hypertensive with LVH $(n=50)$ patients. These groups were included in this study based on clinical signs, ECG findings, and echocardiography data.

\section{Inclusion criteria}

Diagnosed cases of HTN without LVH and with LVH were included and no prior medical treatment for cardiac aliments.

\section{Exclusion criteria}

Patients with diabetes mellitus, chronic kidney disease, viral hepatitis, HIV positive, cancer, myocardial infarction, smokers, and alcoholics were exclude as these conditions may alter the levels of markers in the serum. 
Ethical committee approval was obtained from MIMS, Nellimarla, Vizianagaram. Informed consent was taken from all the participants in this study. The patients were informed about the importance of the study, procedures to be performed and benefits of the study. The blood was drawn from all the participants by venipuncture, and the blood is transferred into plain tube for estimation of NT-proBNP, CK-MB, and myoglobin. The blood samples were preserved at $-40^{\circ} \mathrm{C}$ till further analyses.

\section{Statistical analysis}

The data were expressed as mean and standard deviation. To determine the statistical significance between control and patient groups, the Z-test was carried out by using Microsoft Excel and SPSS software 16.0 (USA). The statistical significance was determined at $5 \%(\mathrm{p}<0.05)$ level.

\section{Blood pressure measurement}

Using mercury sphygmomanometer, the systolic blood pressure (SBP) and diastolic blood pressure (DBP) was measured based on $1^{\text {st }}$ Korotkoff phase and $5^{\text {th }}$ Korotkoff phase. An average of 2 readings was taken into consideration.

ECG

All the individuals enrolled in this study were subjected to 12-lead ECG. The ECG changes were recorded at $25 \mathrm{~mm} / \mathrm{s}$ and $1-\mathrm{mV} / \mathrm{cm}$ calibration. Based on Sokolow-Lyon voltage criteria, the total amplitude of the $\mathrm{S}$ wave in lead $\mathrm{V}_{1}$ and the $\mathrm{R}$ wave in lead $\mathrm{V}_{5}$ or $\mathrm{V}_{6}$ is more than $3.5 \mathrm{mV}$ (35 mm) was considered as LVH [12].

\section{Echocardiography}

LVH diagnosed by ECG was further confirmed using two-dimensional echocardiography. All the echocardiography data were recorded according to the guidelines of the American Society of Echocardiography. Based on Framingham criteria LV mass index more than $131 \mathrm{~g} / \mathrm{m}^{2}$ in male and more than $100 \mathrm{~g} / \mathrm{m}^{2}$ in female was considered. The wall thickness of interventricular septum or the posterior wall if $>1.2 \mathrm{~cm}$ was also considered as LVH [13].

\section{Estimation of serum cardiac markers}

Serum myoglobin, CK-MB was estimated using standard ELISA kit supplied by AccuBind Laboratories (USA) $[14,15]$. The NT-proBNP was estimated using standard ELISA kit from SunRed Laboratories (Shanghai) [16]

\section{RESULTS AND DISCUSSION}

Demographic features and diagnostic parameters

A total of 145 subjects were studied, including 50 normal healthy individuals (control) and 95 HTN diagnosed patients. The HTN group was further divided into HTN without LVH (45) and HTN with LVH (50).

The mean age of the control was $52.46 \pm 11.02$. In case of HTN without $\mathrm{LVH}$ it was $54.8 \pm 10.78$ and HTN with LVH it was $55.24 \pm 11.03$. As regard to the sex distribution, the majority of the subjects in the control group the male were $60 \%$, HTN without LVH is $62 \%$ and HTN with LVH is $54 \%$. It was observed that in this study, SBP and DBP was significantly increased in both hypertensive groups when compared with control $(\mathrm{p}<0.001$; Table 1).

In this, the serum NT-proBNP value was not significantly raised in HTN without LVH group when compared with control. It was also observed that the NT-proBNP is significantly raised in hemodialysis with LVH group when compared to control and hemodialysis without LVH group ( $<<0.001$; Table 2).

The BNP is formed as protein precursor and undergoes modification to forms proBNP (108 amino acids). This will be released into the circulation in response to myocardial stretch [17]. In the blood circulation, it further cleaved into active form BNP (32 amino acids) toward C-terminal side (72 amino acids) inactive NT-proBNP.
The main reason for the increased levels of NT-proBNP in LVH is due to excessive ventricular stretch. The elevated NT-proBNP levels are strongly associated with structural and functional abnormalities of left ventricle along with systolic dysfunction [18]. However, the recent studies shown that NT-proBNP also raised in heart failure and can be used as marker for mortality in acute coronary syndrome and myocardial infarction [19]. The NT-proBNP is mostly cleared from renal system and any dysfunction or failure of renal system reveals the abnormality in the renal function.

NT-proBNP can also acts on kidney and causes the diuresis and tubular natriuresis, by acting against the effect of renin-angiotensin-aldosterone system. The rise of intravascular volume due to heart failure or renal dysfunction, NT-proBNP secretion is also increased and restoration of blood volume by promoting the diuresis. Morillas et al. (2008) showed a significant rise of NT-proBNP level in hypertensive patients with LVH. Helder et al. (2011) reported a correlation between serum NT-proBNP level and LVH. Our study in corroborated with these authors and observed a strong association between LVH and NT-proBNP [20,21].

In this study, the serum levels of CK-MB and myoglobin in HTN without LVH and HTN with LVH groups have not shown any significant change when compared with control (Table 3). Therefore, these two markers may not be considered as markers for $\mathrm{LVH}$.

Table 1: Demographic features of control and cases

\begin{tabular}{llll}
\hline $\begin{array}{l}\text { Demographic } \\
\text { features }\end{array}$ & Mean \pm SD & & \\
\cline { 2 - 4 } & $\begin{array}{l}\text { Control } \\
(\mathbf{n = 5 0 )}\end{array}$ & $\begin{array}{l}\text { HTN without } \\
\text { LVH }(\mathbf{n}=\mathbf{4 5})\end{array}$ & $\begin{array}{l}\text { HTN with } \\
\text { LVH (n=50) }\end{array}$ \\
\hline Age & $52.46 \pm 11.02$ & $54.8 \pm 10.78$ & $55.24 \pm 11.03$ \\
Sex (\%) & & & \\
$\quad$ Males & 60 & 62 & 64 \\
$\quad$ Females & 40 & 38 & 36 \\
SBP (mm Hg) & $118.71 \pm 6.56$ & $146.85 \pm 23.12^{* *}$ & $148.45 \pm 22.12^{* *}$ \\
DBP (mm Hg) & $78.28 \pm 5.12$ & $86.89 \pm 9.01^{* *}$ & $84.89 \pm 8.96^{* *}$ \\
\hline
\end{tabular}

The diagnostic criteria based on SBP and DBP for both the hypertensive groups were significantly higher when compared to control $\left(^{* *} \mathrm{p}<0.001\right)$. SBP: Systolic blood pressure, DBP: Diastolic blood pressure, SD: Standard deviation,

HTN: Hypertension, LVH: Left ventricular hypertrophy

Table 2: NT-proBNP level in control and cases

\begin{tabular}{llll}
\hline Parameter & Mean \pm SD & & \\
\cline { 2 - 4 } & $\begin{array}{l}\text { Control } \\
(\mathbf{n}=\mathbf{5 0})\end{array}$ & $\begin{array}{l}\text { HTN without } \\
\text { LVH }(\mathbf{n}=\mathbf{4 5})\end{array}$ & $\begin{array}{l}\text { HTN with } \\
\text { LVH }(\mathbf{n}=\mathbf{4 5})\end{array}$ \\
\hline $\begin{array}{l}\text { NT-proBNP } \\
(\mathrm{pg} / \mathrm{ml})\end{array}$ & $74.19 \pm 21.40$ & $76.22 \pm 20.14$ & $298.76 \pm 65.76^{* *}$ \\
\hline
\end{tabular}

The mean serum NT-proBNP was increased in HTN with LVH patients when compared to control and HTN without LVH. The increase is statistically significant $\left({ }^{* *} \mathrm{p}<0.001\right)$. SD: Standard deviation, HTN: Hypertension, LVH: Left ventricular hypertrophy, NT-proBNP: N-terminal pro-brain natriuretic peptide

Table 3: CK-MB and myoglobin level in control and cases

\begin{tabular}{llll}
\hline Parameters & \multicolumn{2}{l}{ Mean \pm SD } & \\
\cline { 2 - 4 } & $\begin{array}{l}\text { Control } \\
(\mathbf{n = 5 0})\end{array}$ & $\begin{array}{l}\text { HTN without } \\
\text { LVH }(\mathbf{n = 4 5})\end{array}$ & $\begin{array}{l}\text { HTN with } \\
\text { LVH }(\mathbf{n}=\mathbf{4 5})\end{array}$ \\
\hline $\begin{array}{l}\text { CK-MB } \\
(\mathrm{ng} / \mathrm{ml})\end{array}$ & $3.01 \pm 0.82$ & $3.35 \pm 0.92$ (N.S) & $3.46 \pm 1.03$ (N.S) \\
$\begin{array}{l}\text { Myoglobin } \\
(\mathrm{ng} / \mathrm{ml})\end{array}$ & $58.14 \pm 26.23$ & $60.28 \pm 20.06$ (N.S) & $63.30 \pm 20.90$ (N.S) \\
\hline
\end{tabular}

The mean serum CK-MB and myoglobin has not shown any significant change in both the HTN groups when compared with control. N.S: Not significant, SD: Standard deviation, HTN: Hypertension, LVH: Left ventricular hypertrophy, CK-MB: Creatine kinase-MB 


\section{CONCLUSION}

In the current study, we found that all LVH cases associated with HTN showed marked rise of NT-proBNP levels in serum when compared to HTN without LVH. Hence, the determination of serum NT-proBNP can be considered as a promising marker for LVH screening.

\section{ACKNOWLEDGMENTS}

The authors acknowledge the help and support provided by the Department of Medicine, Maharajah's Institute of Medical Sciences, Nellimarla, Vizianagaram District, Andhra Pradesh, India.

\section{REFERENCES}

1. Mohammed H, Askar ME, Ali SI, Fathy OM. Effect of rennin inhibitors and angiotensin ii receptor antagonists on left ventricular hypertrophy in renovascular hypertensive rats. Int J Pharm Pharm Sci 2015;7(9):292-8.

2. Devereux RB, Casale PN, Eisenberg RR, Miller DH, Kligfield P. Electrocardiographic detection of left ventricular hypertrophy using echocardiographic determination of left ventricular mass as the reference standard. Comparison of standard criteria, computer diagnosis and physician interpretation. J Am Coll Cardiol 1984;3(1):82-7.

3. Frohlich ED, Apstein C, Chobanian AV, Devereux RB, Dustan HP, Dzau V, et al. The heart in hypertension. N Engl J Med 1992;327(14):998-1008.

4. Felker GM, Petersen JW, Mark DB. Natriuretic peptides in the diagnosis and management of heart failure. CMAJ 2006;175(6):611-7.

5. Kroll MH, Srisawasdi P. The clearance of BNP modeled using the NT-proBNP-BNP relationship. Biosystems 2007;88(1-2):147-55.

6. Yeo KT, Wu AH, Apple FS, Kroll MH, Christenson RH, Lewandrowski KB, et al. Multicenter evaluation of the Roche NT-proBNP assay and comparison to the Biosite Triage BNP assay. Clin Chim Acta 2003;338(1-2):107-15.

7. de Lemos JA, McGuire DK, Drazner MH. B-type natriuretic peptide in cardiovascular disease. Lancet 2003;362(9380):316-22.

8. Weber M, Hamm C. Role of B-type natriuretic peptide (BNP) and NT-proBNP in clinical routine. Heart 2006;92(6):843-9

9. Vickery S, Price CP, John RI, Abbas NA, Webb MC, Kempson ME, et al. B-type natriuretic peptide (BNP) and amino-terminal proBNP in patients with CKD: Relationship to renal function and left ventricular hypertrophy. Am J Kidney Dis 2005;46(4):610-20.
10. Wiese S, Breyer T, Dragu A, Wakili R, Burkard T, Schmidt-Schweda S, et al. Gene expression of brain natriuretic peptide in isolated atrial and ventricular human myocardium: Influence of angiotensin II and diastolic fiber length. Circulation 2000;102(25):3074-9.

11. Gomathi R, Vijipriya M, Usha K. Cardioprotective effect of ethanol extract of Medicago sativa stem on isoproterenol induced myocardial infarction in wistar albino rat. Int J Pharm Pharm Sci 2014;6 Suppl 2:839-42.

12. Sokolow M, Lyon TP. The ventricular complex in left ventricular hypertrophy as obtained by unipolar precordial and limb leads. Am Heart J 1949;37(2):161-86.

13. Krumholz HM, Larson M, Levy D. Prognosis of left ventricular geometric patterns in the Framingham Heart Study. J Am Coll Cardiol 1995;25(4):879-84.

14. Apple FS, Christenson RH, Valdes RJ, Andriak AB, Show-Hong D, Feng YJ, et al. Simultaneous rapid measurement of whole blood myoglobin, creatinine kinase $\mathrm{MB}$ and cardiac troponin I by triage cardiac panel for detection of myocardial infarction. Clin Chem 1999;45(2):199-205.

15. Adams JE, Schechtman KB, Landt Y, Ladenson JH, Jaffe AS. Comparable detection of acute myocardial infarction by creatine kinase MB isoenzyme and cardiac troponin I. Clin Chem 1994;40:1291-5.

16. Raju DS, Patnala K. Elucidating the role of cardiac biomarkers in chronic kidney disease. IAJPR 2015;5(9):3013-23.

17. Kinnunen P, Vuolteenaho O, Ruskoaho H. Mechanisms of atrial and brain natriuretic peptide release from rat ventricular myocardium: Effect of stretching. Endocrinology 1993;132(5):1961-70.

18. DeFilippi CR, Fink JC, Nass CM, Chen H, Christenson R. N-terminal pro-B-type natriuretic peptide for predicting coronary disease and left ventricular hypertrophy in asymptomatic CKD not requiring dialysis. Am J Kidney Dis 2005;46(1):35-44.

19. Nielsen LS, Svanegaard J, Klitgaard NA, Egeblad H. N-terminal probrain natriuretic peptide for discriminating between cardiac and noncardiac dyspnoea. Eur J Heart Fail 2004;6(1):63-70.

20. Morillas P, Castillo J, Quiles J, Nuñez D, Guillén S, Maceira A, et al. Usefulness of NT-proBNP level for diagnosing left ventricular hypertrophy in hypertensive patients. A cardiac magnetic resonance study. Rev Esp Cardiol 2008;61(9):972-5.

21. Andrade H, Morillas P, Castillo J, Roldán J, Mateo I, Agudo P, et al. Diagnostic accuracy of NT-proBNP compared with electrocardiography in detecting left ventricular hypertrophy of hypertensive origin. Rev Esp Cardiol 2011;64(10):939-41. 